\title{
APLIKASI PRINCIPAL COMPONENT ANALYSIS UNTUK MENGETAHUI DAYA BELI KENDARAAN BERMOTOR MASYARAKAT INDONESIA
}

\author{
Kartika Rahayu Tri Prasetyo Sari ${ }^{1}$, Widagdo Dwi Nugrahadi Prasetya ${ }^{2}$, Elsanda Merita \\ Indrawati $^{3}$
}

\author{
${ }^{1}$ Prodi Teknik Elektronika / Fakultas Teknik / Universitas Nusantara PGRI Kediri / \\ kartika@unpkediri.ac.id \\ ${ }^{2}$ PLN UPDL Semarang/widagdo.prasetya@gmail.com \\ ${ }^{3}$ Prodi Teknik Elektronika / Fakultas Teknik / Universitas Nusantara PGRI Kediri / \\ elsanda@unpkediri.ac.id
}

\begin{abstract}
The information available for use in decision making is increasing in the present and will continue to grow over time. This is where the role of multivariate statistics works and helps in decision making. Multivariate statistical analysis is an analytical method that makes it possible to examine more than two variables simultaneously. In this study, we will discuss the influence of several variables such as joint-stock index prices, rupiah exchange rates, gold and copper metal mining prices and other variables on the growth of Indonesian people's purchasing power. The method used is principal component analysis (PCA) which is can represent the variables analyzed and examined for their influence on increasing the purchasing power of Indonesian people with the indicator of improvement in the form of increased use of motorized vehicles. From the results of the Principal Component Analysis, the exchange rate variable has a high adverse effect, the joint-stock index variable, the rupiah exchange rate, the gold and copper metal mining prices and the price of airline tickets have a positive influence. The PCA results formed can be used to represent data in knowing people's purchasing power for cars and motorcycles.
\end{abstract}

Keywords : PCA, Variable, Multivariate Statistics

\begin{abstract}
ABSTRAK
Informasi yang tersedia untuk digunakan dalam pengambilan keputusan semakin banyak pada masa sekarang dan akan terus bertambah seiring dengan berjalannya waktu. Disinilah peran statistika multivariat bekerja dan membantu dalam pengambilan keputusan. Analisis statistik multivariat merupakan metode statistik yang memungkinkan dalam meneliti lebih dari dua variabel secara bersamaan.Pada penelitian ini akan diteliti pengaruh beberapa variabel seperti harga indeks saham gabungan, nilai tukar rupiah, harga tambang logam emas dan tembaga dan variabel lainnya terhadap pertumbuhan daya beli masyarakat Indonesia. Metode yang digunakan adalah principal component Analysis (PCA) yang mampu merepresentasikan variabel-variabel yang dianalisis dan diteliti pengaruhnya terhadap peningkatan daya beli masyarakat Indonesia dengan indikator peningkatan tersebut berupa peningkatan penggunaan kendaran bermotor. Dari hasil Principal Component Analysis variabel kurs memberi pengaruh negatif yang tinggi, variabel indeks saham gabungan, nilai tukar rupiah, harga tambang logam emas dan tembaga dan harga tiket pesawat memberi pengaruh positif. Hasil PCA yang dibentuk dapat digunakan untuk mewakili data dalam mengetahui daya beli masyarakat terhadap mobil dan motor.
\end{abstract}

Kata Kunci : PCA, Variabel, Statistik Multivariat

\section{PENDAHULUAN}

Informasi yang tersedia untuk digunakan dalam pengambilan keputusan semakin banyak pada masa sekarang dan akan terus bertambah seiring dengan berjalannya waktu. Sebagian data dapat diolah dan dimengerti dengan perhitungan statistik yang mudah, namun sebagian besar data membutuhkan teknik statistika yang lebih kompleks untuk mengubah data tersebut menjadi 
sebuah informasi yang berguna. Statistika multivariat bekerja dan membantu dalam pengambilan keputusan, analisis statistik multivariat merupakan metode statistik yang memungkinkan dalam meneliti lebih dari dua variabel secara bersamaan (Firdaus, 2009). Salah satu contoh penggunaan analisis multivariat adalah untuk mengetahui pengaruh kecepatan layanan, keramahan petugas dan kejelasan dalam memberikan informasi terhadap kepuasan dan loyalitas pelanggan. Analisis multivariat digunakan karena pada sistem aktual, masalah yang terjadi tidak dapat diselesaikan dengan hanya menghubungkan dua variabel atau melihat pengaruh satu variabel terhadap variabel lainnya. Seperti contoh masalah sebelumnya, variabel kepuasan pelanggan dipengaruhi tidak hanya oleh kualitas produk tetapi juga oleh harga dan distribusi produk tersebut. Teknik analisa multivariat sangat populer dikarenakan teknik ini membantu dalam pengambilan keputusan dalam suatu organisasi. Analisa multivariat menggambarkan teknik-teknik statistik yang secara simultan menganalisa banyak ukuranukuran dalam satu atau banyak objek yang diteliti (Hair, 2006). Berbagai macam teknik dalam analisa multivariat merupakan pengembangan dari analisa univariat dan bivariat seperti ANOVA, atau regresi linier (Joseph, 2002).

Analisis multivariat dimulai dengan data yang memiliki banyak variabel yang saling berkaitan (correlated). PCA merupakan tool statistik yang digunakan untuk menghilangkan collinearity data dengan mengkompresi dan mengklasifikasikan data (Jackson, 1991). Hasil akhir dari penghilangan collinearity data tersebut yang dimaksud dengan principal component, sehingga tujuan dari PCA adalah mengubah sejumlah variabel-variabel yang saling berkaitan menjadi sejumlah (atau lebih kecil) variabel-variabel bebas (uncorrelated). Principal component pertama menunjukkan seberapa besar variabilitas dari data yang dimiliki. Tujuan dari penggunaan PCA adalah mengurangi dimensionalitas data atau kompresi data dan digunakan untuk memilih subset dari variabel-variabel dimulai dari set yang lebih besar berdasarkan variabel awal yang memiliki korelasi terbesar dalam principal component (Abdurachman, 2010). PCA pada dasarnya bekerja pada sekelompok data observasi yang pada awalnya memiliki kemungkinan saling berkorelasi, kemudian proses PCA mengkonversi data tersebut sedemikian rupa sehingga yang tersisa adalah data yang tidak saling berkorelasi satu sama lain yang disebut dengan principal component (Edward, 1991). Jumlah principal component yang dihasilkan adalah kurang dari atau sama dengan jumlah data aslinya.

Beberapa tahapan harus dilalui dalam melakukan analisis multivariat dengan PCA, tahapan tersebut diantaranya, menentukan data yang akan dianalisis, mengurangi data dengan rata-rata (centering), menentukan Kovarian dari data, menentukan eigenvectors dan eigenvalues dari kovarian matriks, memilih komponen dan membentuk sebuah feature vector, menurunkan persamaan baru dan melakukan perkalian antara persamaan yang dihasilkan dalam PCA dengan mendapatkan data lama kembali (Jackson, 1991). Dengan demikian, PCA sangat cocok digunakan untuk analisis data multi dimensi. PCA bermanfaat dalam screening data multivariat. Untuk hampir semua analisis data, PCA dapat direkomendasikan sebagai langkah awal dalam melakukan analisis. PCA dapat dilakukan sebelum analisis multivariat dan PCA juga dapat digunakan untuk membantu mengungkap ketidaknormalan yang ada pada data multivariat.

Terdapat beberapa penelitian yang telah dilakukan oleh beberapa peneliti terdahulu yaitu tentang peramalan pertumbuhan ekonomi dengan berbagai macam metode, penggunaan metode VAR (Vector Auto Regressive) dilakukan untuk peramalan produksi suatu industri dalam jangka pendek (Blake dkk, 2000 ). VAR juga digunakan untuk peramalan GDP dan dilanjutkan ke tahapan penghitungan error menggunakan Root Mean Square Forecasting Error (RMSFE). Model ALI (Auto Leading Indicator) dilakukan untuk peramalan pertumbuhan GDP (ChambaMendez dkk, 2001). PCA digunakan dalam peramalan GDP dalam mencari faktor umum dari banyak indikator dalam menentukan komponen peramalan GDP (Klein Ozmucur, 2001). PCA digunakan untuk mereduksi variabel yang diperoleh dari sumber data eksternal untuk 
meramalkan GDP (Chamberlin, 2007), dan selain itu PCA digunakan untuk menentukan indikator yang berpengaruh utama terhadap besarnya GDP negara Indonesia (Sari, 2017).

Pada penelitian ini akan diteliti pengaruh beberapa variabel seperti harga indeks saham gabungan, nilai tukar rupiah, harga tambang logam emas dan tembaga dan variabel lainnya terhadap pertumbuhan daya beli masyarakat Indonesia. Nantinya hasil dari PCA yang dinamakan principal component yang mampu merepresentasikan variabel-variabel yang dianalisis akan diteliti pengaruhnya terhadap peningkatan daya beli masyarakat Indonesia dengan indikator peningkatan tersebut berupa peningkatan penggunaan kendaran bermotor yaitu sepeda motor dan mobil di Indonesia pada tahun yang sama, yaitu tahun 1995 dan 2010.

\section{METODE PENELITIAN}

Dalam penelitian ini, data yang dimiliki adalah data bulanan harga emas dan tembaga, nilai tukar rupiah, GDP, poin IHSG dan harga tiket pesawat Yogyakarta-Jakarta dari tahun 19952010. Keenam data ini akan dianalisis dengan menggunakan principal component analysis (PCA). Pengerjaan diawali dengan mengumpulkan data bulan dan tahunan dari keenam variabel pada tahun Januari 1995 sampai Desember 2010, pemilihan data menggunakan rentang data tahun 1995-2010 dikarenakan terdapat peningkatan data yang sama dalam penggunaan kendaraan motor dan mobil sehingga yang digunakan yaitu rentang data selama 15 tahun yaitu tahun 1995-2010. Kemudian dilakukan pengecekan range data dan karena range data berbeda maka dikakukan scaling pada data. Setelah itu dilakukan PCA dengan aturan sebagai berikut:

a. Skenario 1, pengolahan data bulanan dengan PCA

b. Skenario 2, pengolahan data tahunan dengan PCA

c. Skenario 3, pengolahan data tahunan, tanpa variabel kurs rupiah terhadap dolar.

Setelah diketahui PCA bulan dan tahun, dilakukan skenario 4 yaitu perbandingan hasil PCA dengan data dari jumlah pembelian motor dan mobil pada tahun 1995 sampai 2010, kemudian diambil kesimpulan dari sejumlah perhitungan dan analisis yang telah dilakukan.

\section{HASIL DAN PEMBAHASAN}

Data yang dimiliki adalah data bulanan harga emas dan tembaga, nilai tukar rupiah, GDP, poin IHSG dan harga tiket pesawat Yogyakarta-Jakarta dari tahun 1995-2010. Tabel 1 merupakan ringkasan keenam data yang akan dianalisis.

Tabel 1. Ringkasan Analisis Data

\begin{tabular}{llllll}
\hline No & Nama Variabel & Minimum & Maksimum & Rata-Rata & $\begin{array}{c}\text { Standar } \\
\text { Deviasi }\end{array}$ \\
\hline $\mathbf{1}$ & Harga Emas & 26000 & 502000 & 126137,1 & 100468,1038 \\
$\mathbf{2}$ & Kurs IDR-USD & 2229 & 15160 & 8174,833 & 2929,251382 \\
$\mathbf{3}$ & GDP Indonesia & 106458,80 & 2049670,30 & 604921,28 & 467976,93 \\
$\mathbf{4}$ & TAU JOG-CGK & 37100,6 & 980675,35 & 418909,9 & 230398,176 \\
$\mathbf{5}$ & Level IHSG & 276,15 & 3703,51 & 1077,90 & 842,92 \\
$\mathbf{6}$ & Harga Tembaga & 4,528064 & 91,64522 & 31,03595 & 25,08902241 \\
\hline
\end{tabular}


Hasil dan pembahasan akan dibagi menjadi empat bagian, yaitu pada data bulanan, data tahunan dan perbandingan hasil PCA dengan data lain yaitu berupa jumlah penggunaan mobil dan motor pada tahun 1995-20120. Hal ini dilakukan sebagai indikasi peningkatan daya beli masyarakat yang dipengaruhi oleh variabel-variabel awal yang terjadi di Indonesia yaitu $\mathrm{X}_{1}$ (Harga Jual Emas), $\mathrm{X}_{2}$ (Nilai tukar rupiah terhadap dolar, $\mathrm{X}_{3}$ (GDP), $\mathrm{X}_{4}$ (Tiket Angkutan Udara JOG-CGK), $\mathrm{X}_{5}$ (Poin IHSG), dan $\mathrm{X}_{6}$ (Harga Tembaga).

\subsection{Skenario 1}

Analisis yang dilakukan pada skenario 1 menggunakan data bulanan dari Januari 1995 sampai dengan Desember 2010 untuk masing-masing variabel, sehingga data yang diperoleh sebanyak 192 untuk setiap variabel. Setelah sejumlah 192 data dilakukan scaling, diperoleh hasil PCA pada Tabel 2.

Tabel 2 Hasil PCA pada Skenario 1

\begin{tabular}{|c|c|c|c|c|c|c|c|c|c|}
\hline \multirow{2}{*}{$\begin{array}{l}\text { Variabel } \\
\text { Baru }\end{array}$} & \multirow{2}{*}{$\begin{array}{l}\text { Eigen } \\
\text { Value }\end{array}$} & \multirow{2}{*}{$\begin{array}{l}\text { Rasio } \\
\text { Eigen } \\
\text { Value }\end{array}$} & \multirow{2}{*}{$\begin{array}{c}\text { Prosentase } \\
\text { Kumulatif } \\
\text { Eigen } \\
\text { Value }\end{array}$} & \multicolumn{6}{|c|}{ Koefisien Loading } \\
\hline & & & & $\mathrm{X1}$ & $\mathrm{X} 2$ & $\mathbf{X 3}$ & $\mathrm{X4}$ & $\mathbf{X 5}$ & X6 \\
\hline PCA 1 & 4.983 & 0.838 & $83.79 \%$ & 0.421 & 0.292 & 0.430 & 0.433 & 0.414 & 0.425 \\
\hline PCA 2 & 0.763 & 0.145 & $95.55 \%$ & 0.075 & -0.881 & 0.114 & -0.118 & 0.393 & 0.14 \\
\hline PCA 3 & 0.136 & 0.034 & $97.79 \%$ & -0.650 & 0.134 & -0.320 & -0.098 & 0.182 & 0.732 \\
\hline PCA 4 & 0.080 & 0.013 & $99.24 \%$ & 0.46 & 0.253 & -0.159 & -0.785 & 0.268 & 0.064 \\
\hline PCA 5 & 0.030 & 0.005 & $99.78 \%$ & 0.208 & -0.164 & 0.330 & -0.208 & -0.736 & 0.484 \\
\hline PCA 6 & 0.013 & 0.002 & $100 \%$ & -0.494 & 0.139 & 0.747 & -0.356 & 0.161 & -0.156 \\
\hline
\end{tabular}

Untuk nilai eigen value batas prosentase kumulatif pada skenario 1 sudat dapat mencapai $80 \%$, sehingga hasil dari Tabel 2 dapat diketahui PCA 1 dapat mewakili keseluruhan data sebesar 83,79\%. Hasil dari PCA 1 ini akan mengabaikan 16,21\% dari total 1155 data yang didapatkan. Koefisien loading dari PCA 1 mempunyai perngaruh pada persamaan PCA 1, yaitu:

$Z_{1}=0.421 X_{1}+0.292 X_{2}+0.430 X_{3}+0.433 X_{4}+0.414 X_{5}+0.425 X_{6}$

Dari hasil PCA pada persamaan 1 diketahui variabel harga jual emas, GDP, Tiket Angkutan Udara, IHSG, dan Harga Tembaga mempunyai nilai koefisien loading yang hampir sama yaitu sekitar 0,4 dan GDP memiliki koefisien yang paling tinggi. Variabel kurs rupiah memiliki koefisien yang paling kecil. Jika hasil PCA ini dibandingkan dengan variabel-variabel awal pembentuknya terdapat dalam Gambar 1. 


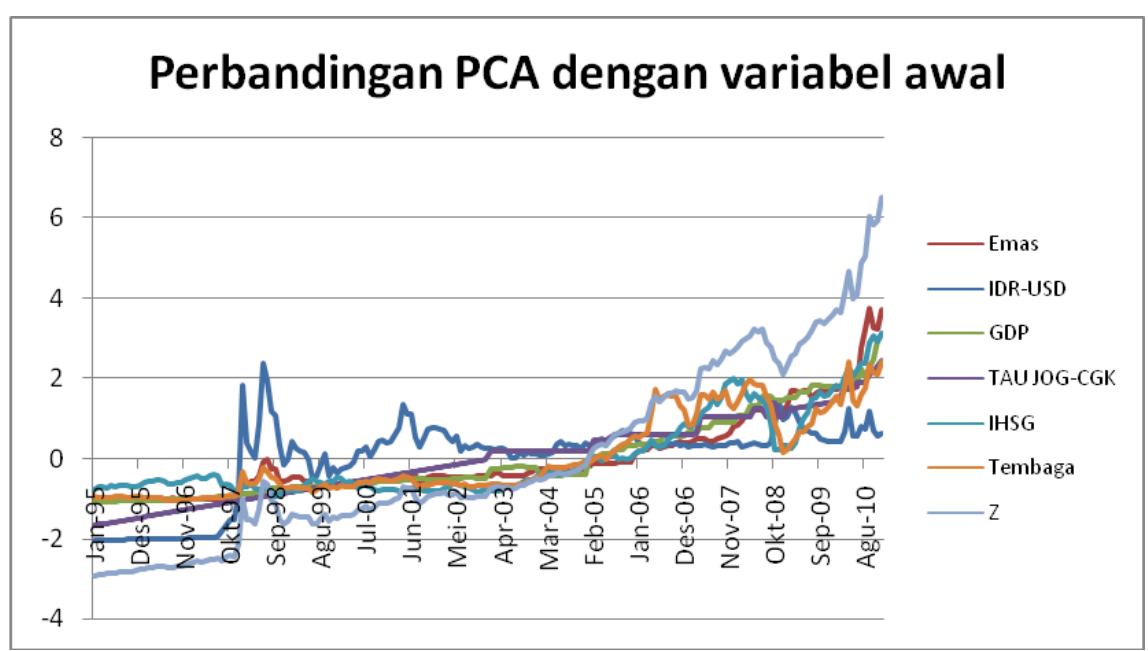

Gambar 1. PCA Terhadap Variabel Awal Pada Kondisi 1

Dari Gambar 1 dapat diketahui bahwa diantara keenam variabel, kurs rupiah terhadap dolar (IDR-USD) memiliki grafik yang cenderung berbeda daripada variabel lainnya. Hal ini juga dapat dilihat pada persamaan 1 dimana kurs IDR-USD memiliki koefisien loading paling kecil.

\subsection{Skenario 2}

Untuk skenario 2 data yang yang digunakan adalah data tahunan. Variabel yang digunakan untuk analisis data tahunan ini sama dengan variabel pada skenario 1. Pada skenario 2 menggunakan data tahunan untuk mengetahui pola data yang dihasilkan secara umum pada tahun tersebut. Data yang digunakan untuk perhitungan adalah data tahun 1995 sampai dengan tahun 2010, terdapat 97 data untuk setiap variabel yang akan dianalisis untuk perhitungan skenario 2. Tabel 3 adalah hasil dari perhitungan untuk data tahunan.

Tabel 3. Hasil PCA pada skenario 2

\begin{tabular}{|c|c|c|c|c|c|c|c|c|c|}
\hline \multirow{2}{*}{$\begin{array}{c}\text { Variabel } \\
\text { Baru }\end{array}$} & \multirow{2}{*}{$\begin{array}{l}\text { Eigen } \\
\text { Value }\end{array}$} & \multirow{2}{*}{$\begin{array}{l}\text { Rasio } \\
\text { Eigen } \\
\text { Value }\end{array}$} & \multirow{2}{*}{$\begin{array}{c}\% \\
\text { Kumulatif } \\
\text { Eigen } \\
\text { Value }\end{array}$} & \multicolumn{6}{|c|}{ Koefisien Loading } \\
\hline & & & & X1 & $\mathbf{X} 2$ & $\mathbf{X 3}$ & $\mathrm{X4}$ & $\mathrm{X5}$ & X6 \\
\hline PCA 1 & 4.65 & 0.773 & $77 . .31 \%$ & 0.42 & 0.25 & 0.45 & 0.43 & 0.43 & 0.42 \\
\hline PCA 2 & 0.97 & 0.164 & $96.75 \%$ & 0.21 & -0.85 & 0.22 & -0.31 & 0.14 & 0.20 \\
\hline PCA 3 & 0.15 & 0.018 & $98.18 \%$ & -0.45 & 0.05 & -0.40 & -0.16 & 0.35 & 0.67 \\
\hline PCA 4 & 0.07 & 0.012 & $99.35 \%$ & 0.01 & -0.01 & -0.19 & -0.08 & 0.80 & -0.55 \\
\hline PCA 5 & 0.03 & 0.005 & $99.88 \%$ & 0.57 & 0.36 & -0.16 & -0.69 & -0.03 & 0.12 \\
\hline PCA 6 & 0.007 & 0.001 & $100.00 \%$ & -0.46 & 0.24 & 0.71 & -0.44 & 0.09 & -0.05 \\
\hline
\end{tabular}

Untuk standar nilai batas prosentase kumulatif eigen value adalah sebesar $80 \%$. Hasil perhitungan pada Tabel 3 dapat diketahui bahwa PCA 1 dan PCA 2 yang di hasilkan pada perhitungan skenario 2 dapat mewakili keseluruhan data sebesar 96,75\%. Hasil PCA 1 ini akan 
mengabaikan 3,25\% dari total 97 data yang diperoleh. Koefisien loading dari PCA 1 dan PCA 2 terdapat dalam persamaan 2 dan 3.

$Z_{1}=0.42 X_{1}+0.25 X_{2}+0.43 X_{3}+0.43 X_{4}+0.43 X_{5}+0.42 X_{6}$

$Z_{2}=0.21 X_{1}-0.85 X_{2}+0.22 X_{3}-0.31 X_{4}+0.14 X_{5}+0.20 X_{6}$

$\mathrm{Z}$ total hasil dari perhitungan pada persamaan 3 dan 4 terdapat pada persamaan 4

$Z=0.63 X_{1}-0.60 X_{2}+0.65 X_{3}+0.12 X_{4}+0.57 X_{5}+0.62 X_{6}$

Dari hasil perhitungan pada persamaan 4 dapat diketahui bahwa dari keenam variabel hanya variabel kurs rupiah terhadap dolar yang memiliki nilai negatif besar, sehingga kurs rupiah mempunyai nilai yang berbanding terbalik dengan 5 variabel lainnya. Untuk variabel yang paling besar adalah variabel GDP dan variabel positif yang paling kecil adalah tarif angkutan udara. Gambar 2 adalah perbandingan PCA dengan variabel awal.

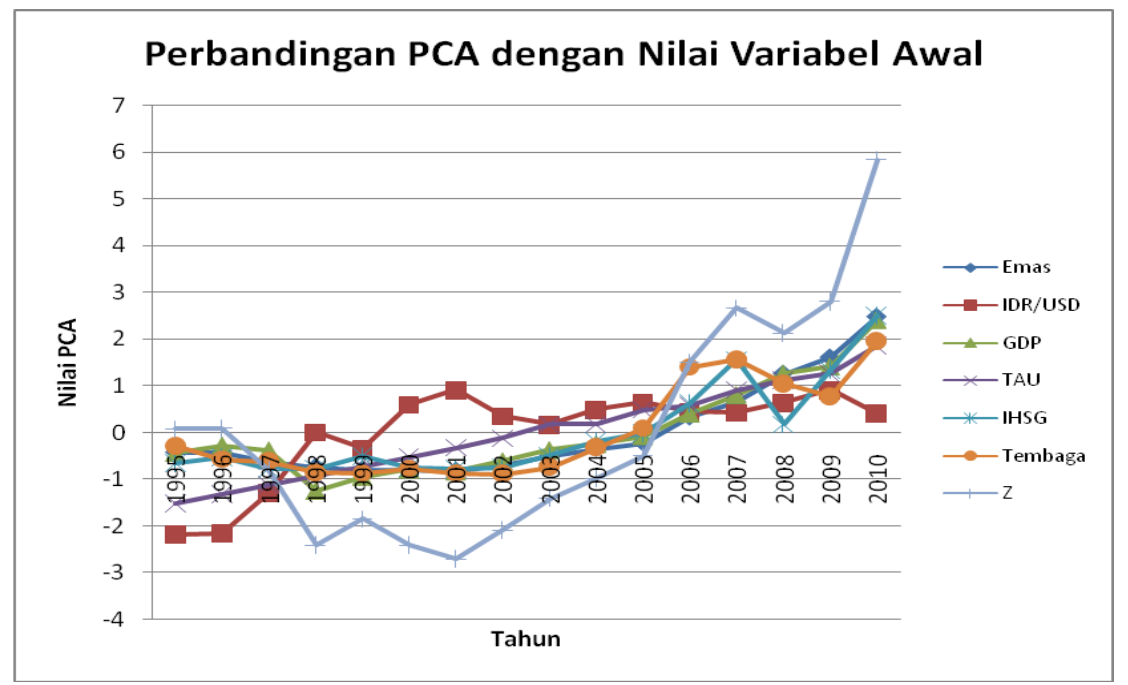

Gambar 2. Perbandingan PCA dengan Variabel Awal

Pada Gambar 2 diketahui bahwa terdapat perbedaan yang mencolok pada sekitar tahun 19992002, dengan nilai kurs rupiah terhadap dolar mengalami kenaikan sedangkan pada nilai PCA mengalami hal yang sebaliknya, yaitu penurunan nilai. Hal ini disebabkan oleh pengaruh nilai kurs rupiah yang berbanding terbalik dengan nilai daripada variabel lainnya, dimana pada tahun tersebut nilai pada variabel lainnya cenderung naik atau turun dengan kondisi yang tidak signifikan sedangkan nilai kurs rupiah naik secara signifikan. Dengan kondisi seperti ini menyebabkan persamaan untuk membentuk PCA, variabel kurs rupiah memberikan pengaruh yang berbeda dengan variabel lainnya. Sehingga pada skenario berikutnya, variabel kurs rupiah akan dihilangkan.

\subsection{Skenario 3}

Seperti yang telah dijelaskan pada sub bab sebelumnya, pada perhitungan skenario 3 kurs rupiah dihilangkan, karena variabel kurs rupiah mempunyai pengaruh terbalik yang berpengaruh untuk membentuk PCA dari hasil perhitungan yang terdapat pada persamaan 4. Untuk perhitungan pada skenario 3 variabel yang digunakan adalah, variabel 1 (harga jual emas), variabel 3 (GDP), variabel 4 (Harga tiket pesawat), variabel 5 (IHSG), dan variabel 6 (harga tembaga). Hasil perhitungan setelah data kurs dihilangkanuntuk pembentukan PCA terdapat dalam Tabel 4.

Tabel 4 Hasil PCA pada Skenario 3 


\begin{tabular}{|c|c|c|c|c|c|c|c|c|}
\hline \multirow{2}{*}{$\begin{array}{c}\text { Variabel } \\
\text { Baru }\end{array}$} & \multirow{2}{*}{$\begin{array}{l}\text { Eigen } \\
\text { Value }\end{array}$} & \multirow{2}{*}{$\begin{array}{l}\text { Rasio } \\
\text { Eigen } \\
\text { Value }\end{array}$} & \multirow{2}{*}{$\begin{array}{c}\% \\
\text { Kumulatif } \\
\text { Eigen } \\
\text { Value }\end{array}$} & \multicolumn{5}{|c|}{ (Koefisien Loading) } \\
\hline & & & & X1 & $\mathbf{X 3}$ & $\mathrm{X} 4$ & $\mathrm{X5}$ & X6 \\
\hline PCA 1 & 4.5481 & 0.90962 & $91.96 \%$ & 0.456 & 0.467 & 0.424 & 0.452 & 0.444 \\
\hline PCA 2 & 0.2244 & 0.04488 & $96.45 \%$ & -0.176 & -0.185 & 0.894 & -0.141 & -0.337 \\
\hline PCA 3 & 0.1369 & 0.02738 & $98.19 \%$ & 0.535 & 0.469 & -0.080 & -0.339 & -0.609 \\
\hline PCA 4 & 0.0761 & 0.01522 & $99.71 \%$ & 0.027 & -0.183 & -0.113 & 0.805 & -0.550 \\
\hline PCA 5 & 0.01 & 0.0029 & $100.00 \%$ & 0.688 & -0.708 & 0.015 & -0.104 & 0.114 \\
\hline
\end{tabular}

Hasil nilai batas prosentase kumulatif eigen value adalah sebesar $80 \%$. Hasil perhtungan pada Tabel 4 dapat diketahui bahwa PCA 1 dapat mewakili keseluruhan data sebesar 91,96\%. Hasil perhitungan PCA 1 akan mengabaikan $8,04 \%$ dari total 80 data yang diperoleh. Koefisien loading dari PCA 1 terdapat pada persamaaan 5.

$Z_{1}=0.456 X_{1}+0.467 X_{3}+0.4242 X_{4}+0.4522 X_{5}+0.4449 X_{6}$

Hasil perhitungan pada persamaan 5 dapat diketahui bahwa kelima variabel mempunyai pengaruh yang hampir sama pada pembentukan PCA, kelima variabel menyumbang sekitar 0,4 dibandingkan variabel awalnya untuk membentuk PCA. Untuk perbandingan PCA dengan variabel awal kecuali kurs rupiah terdapat dalam Gambar 3.

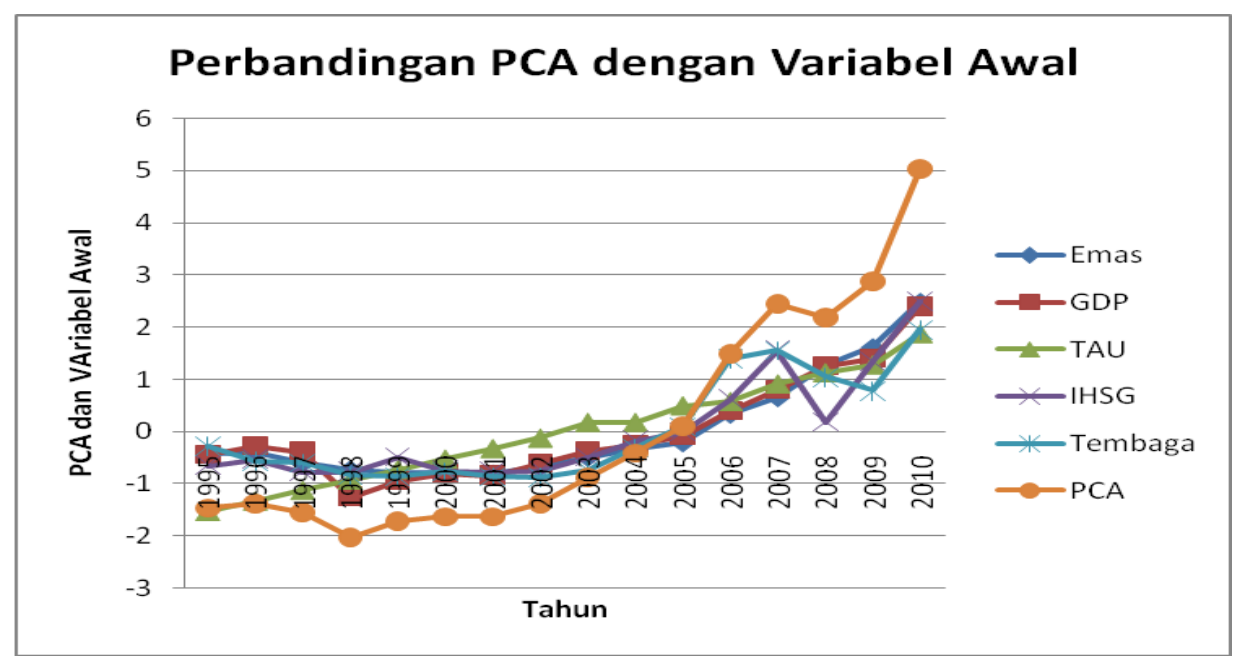

Gambar 3. Perbandingan PCA dengan Variabel Awal

\subsection{Skenario 4}

Pada skenario 4 akan dilakukan perbandingan hasil PCA pada skenario 3 dengan data lain. Perbandingan ini dilakukan untuk mengetahui apakah hasil dari scenario 3 sudah merepresentasikan keadaan daya beli masyarakat yang dipengaruhi variabel-variabel yang telah didapatkan yaitu variabel 1 (harga jual emas), variabel 3 (GDP), variabel 4 (Harga tiket pesawat), variabel 5 (IHSG), dan variabel 6 (harga tembaga). Data yang dibandingkan adalah jumlah mobil dan motor pada tahun 1995-2010 terdapat pada Gambar 4. 
Jurnal Inkofar * Volume 5 No. 1, Juli 2021 * E-ISSN: 2581-2920

Tersedia secara online di: http://www.politeknikmeta.ac.id/meta/ojs/

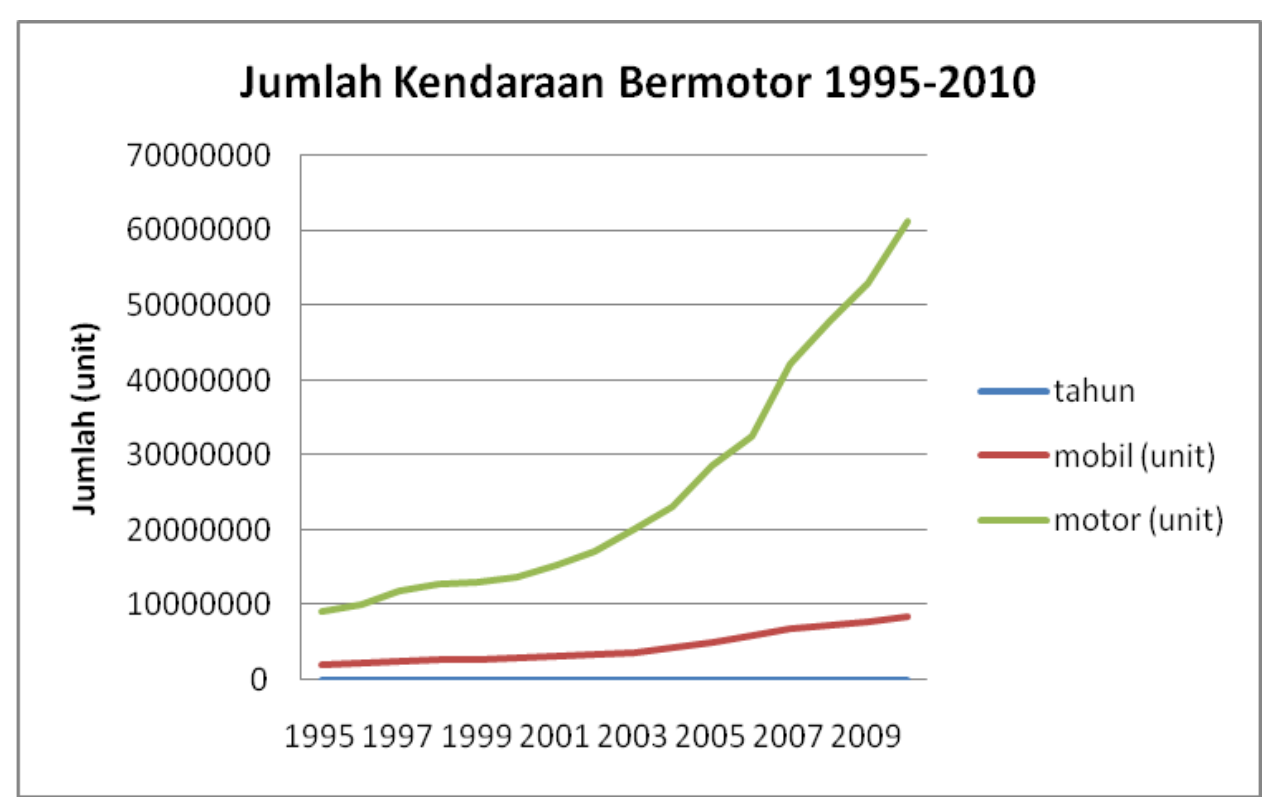

Gambar 4. Grafik Kenaikan Jumlah Kendaraan bermotor di Indonesia tahun 1995-2010

Data penggunaan kendaraan ini kemudian discaling karena memiliki satuan yang berbeda dengan PCA sebelumnya yang berupa satuan uang, kemudian dari hasil scaling tersebut akan dilihat korelasi antara PCA dengan data penggunaan mobil dan motor. Perhitungan hasil korelasi terdapat dalam Tabel 5.

Tabel 5. Korelasi antar PCA dengan data penggunaan mobil dan motor tahun 19952010

\begin{tabular}{lrrrr}
\hline & Mobil & Motor & $\begin{array}{c}\text { PCA } \\
\text { tahun }\end{array}$ & $\begin{array}{c}\text { PCA } \\
\text { bulan }\end{array}$ \\
\hline Mobil & 1 & 0.993725 & 0.972893 & 0.986628 \\
Motor & 0.993725 & 1 & 0.980913 & 0.985134 \\
$\begin{array}{l}\text { PCA } \\
\text { tahun }\end{array}$ & 0.972893 & 0.980913 & 1 & 0.958488 \\
$\begin{array}{l}\text { PCA } \\
\text { bulan }\end{array}$ & 0.986628 & 0.985134 & 0.958488 & \\
\hline
\end{tabular}

Dari Tabel 5 diketahui bahwa korelasi antara ketiga variabel tersebut memiliki korelasi yang kuat, sehingga dapat dibandingkan diantara ketiganya dalam Gambar 5. 


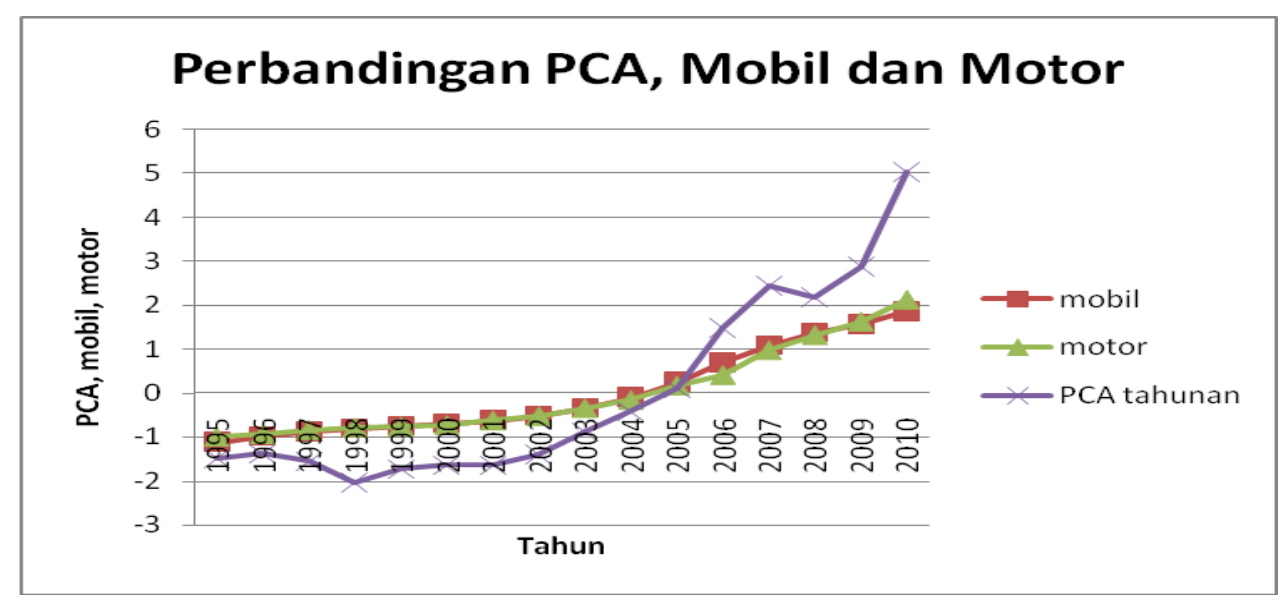

Gambar 5 Perbandingan PCA, mobil dan motor

Dari gambar 5 diketahui bahwa hubungan PCA, penggunaan mobil dan motor memiliki pola yang hampir sama, sehingga PCA yang telah dibentuk pada skenario 3 dapat mewakili penentuan daya beli masyarakat dengan indikator penggunaan kendaraan bermotor, dalam hal ini adalah produk motor dan mobil, sedangkan jika dihubungan dengan skenario 1 , hasil perbandingan terdapat dalam Gambar 6.

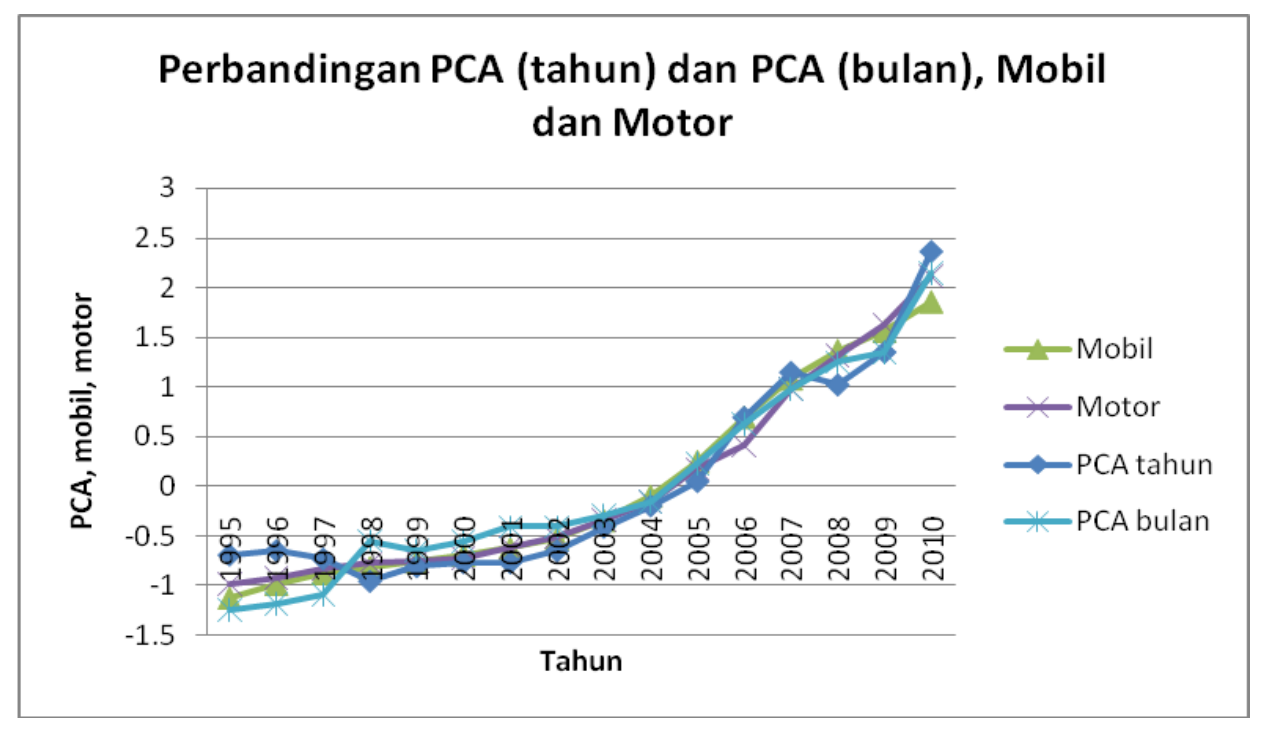

Gambar 6. Perbandingan PCA dari data tahun, PCA dari data bulan, mobil dan motor

Gambar 6 merepresentasikan bahwa PCA pada skenario 1 dan skenario 3 dapat digunakan untuk merepresentasikan daya beli masyarakat terhadap suatu produk. Dimana menggunakan data bulanan, keenam variabel dapat digunakan untuk membentuk variabel PCA sedangkan jika dengan menggunakan data tahunan, untuk membentuk PCA baru digunakan lima variabel awal yaitu harga emas, GDP, IHSG, Harga Tiket dan harga tembaga.

Dari ketiga skenario yang telah dilakukan, pengaruh dari eigen vector untuk masing-masing variabel terdapat dalam Gambar 7. 


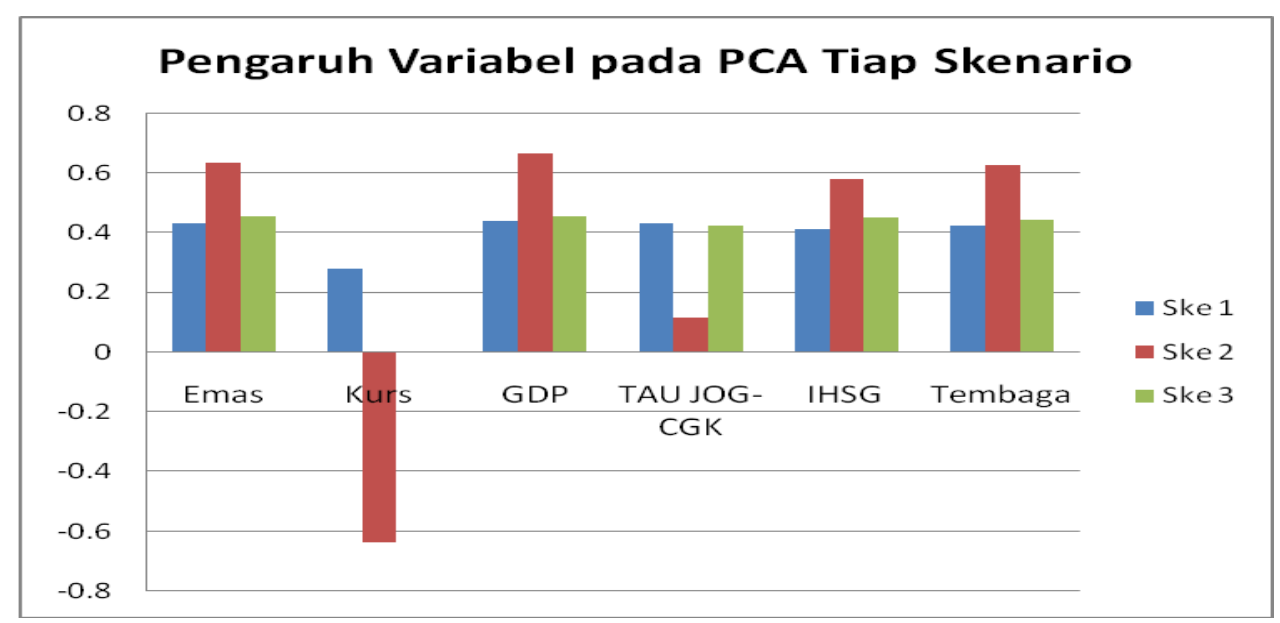

Gambar 7. Pengaruh Variabel pada PCA tiap skenario

Dari gambar 7 dapat disimpulkan bahwa untuk mengetahui daya beli masyarakat terhadap motor dan mobil pada skenario 1 dan 3 memiliki nilai eigen vector yang hampir sama. Hal ini sangat berbeda pada skenario 2, dimana komposisi dari tiap variabel jauh berbeda. Pengaruh dari kurs memberi dampak yang sangat besar pada data tahunan maupun pada data bulanan. Pada data bulanan dampak yang diberikan paling kecil bila dibandingkan dengan kelima variabel yang lain, sedangkan pada data tahunan, nilai kurs malah memberikan nilai negatif yang sangat besar.

\section{KESIMPULAN}

Kesimpulan yang didapat dari perhitungan dan analisis yang telah dilakukan adalah sebagai berikut :

1. Principal Component Analysis dapat digunakan untuk membentuk variabel baru dengan mengurangi dimensi dari variabel pembentuknya. Pada skenario 1 dan 3 terbentuk 1 PCA sedangkan pada skenario 2 terbentuk 2 PCA

2. Variabel yang tidak mempengaruhi pembentukan Principal Component Analysis pada daya beli masyarakat pada produk motor dan mobil adalah kurs uang, dimana ketika dalam membentuk PCA variabel lain memberi pengaruh positif tetapi variabel kurs memberi pengaruh negative yang tinggi

3. Principal Component Analysis yang dibentuk dapat digunakan untuk mewakili data dalam mengetahui daya beli masyarakat terhadap mobil dan motor.

\section{DAFTAR PUSTAKA}

Abdurachman. 2010. Diktat Statistik Multivariate. Pascasarjana Teknik Industri, Jurusan Teknik Mesin dan Industri, Jogjakarta.

Blake A, Kapetanios G, Weale M. R. 2000. National Institute of Economic and Social Research. Nowcasting EU Industrial Production and Manufacturing Output.

Chamba-Mendez G, Kapetanios G, Smith RJ, Weale M. R. 2001. An Automatic Leading Indicator of Economic Activity:Forecasting GDP Growt for Europian Countries. Econometrics Journal. Vol 4 pp 56-90

Chamberlin, Graeme. 2007. Forecasting GDP Using External Data Sources. Economic and Labour Market Review. Vol. 1 No.8 pp 18-23.

Firdaus, A. 2009. Analisis Keputusan, Pusat Pengembangan Bahan Ajar- UMB.

Edward, J.E. 1991. A User Guide To Principal Components, John Willey and Sons, Canada.

Hair, J, F., et al., 2006. Multivariate Data Analysis, 6th ed, Pearson Education, Inc., Upper Saddle River, NJ.

Jackson, J.E. 1991. A User's Guide to Principal Components, John Wiley \& Sons, Inc, 1991. 
Joseph, F.H., et al., 2002, Applied Multivariate Statistical Analysis, $5^{\text {th }}$ edition, Pearson Education International.

Klein RL and Ozmucur S. 2001. Te Predictive Power of Survey Results in Macroeconomic Analysis. Macromodels Journal, Krag Poland

Sari, KRTP, 2017. Prediksi Nilai Gross Domestic Product (GDP) Perkapita Indonesia dengan Metode Principal Component Analysis (PCA) dan Regresi. Prosiding Seminar Nasional Inovasi Teknlogi. 